\title{
SUITABILITY OF WASTEWATER SLUDGE FOR UTILIZATION IN THE LENINGRAD REGION (RUSSIA)
}

\author{
Hanna Värri \\ Jouni Havukainen \\ Mika Horttanainen \\ Lappeenranta University of Technology, Finland
}

\begin{abstract}
Insufficient wastewater treatment causes serious problems for the environment and health in the Leningrad Region. Even though wastewater treatment has been improving during the last decade, almost no attention has been paid to the wastewater sludge treatment. Nutrient emissions from the organic wastes, including wastewater sludge, are among the most significant sources of the eutrophication of the Baltic Sea. Disposal of sludge causes also significant greenhouse gas emissions, polluting local water resources and filling up the landfill sites.

Currently the main treatment method of wastewater sludge in Russia is so called aging. This means that sludge is stored in piles from some months up to some years, and after that the sludge is disposed to landfills. In order to develop wastewater sludge treatment, it is essential to know the properties of the material treated. In Russia, wastewater sludge is often expected to contain high amounts of heavy metals. This is a significant challenge for material or energy recovery from the sludge. Different possible treatment methods of wastewater sludge are discussed in this paper.

The properties and composition of wastewater sludge from two different municipal wastewater treatment plants are defined and discussed in the paper. The main properties are volatile and total solids, moisture and ash content, inorganic compounds, heavy metal contents, and the lower heating value of dry matter. The effect of the properties on energy and nutrient recovery purposes are evaluated.
\end{abstract}

\section{KEYWORDS}

Wastewater sludge, Heavy metals, Energy recovery, Nutrients

\section{INTRODUCTION}

\subsection{Characteristics of wastewater sludge}

Wastewater sludge is a by-product of the wastewater treatment process. The characteristics of wastewater sludge depend on the characteristics of the wastewater treated and on the technical characteristics of the wastewater treatment method.

Typical properties of wastewater sludge are presented in table 1. 
Heavy metals tend to concentrate in wastewater sludge. The Amount of heavy metals is strongly related to the origin of the wastewater sludge. The average content of heavy metals in European Union countries is presented in table 2.

\subsection{Technologies for wastewater sludge treatment}

Sewage sludge treatment methods include anaerobic digestion (AD), composting, combustion, thermal drying and conditioning of sludge [4]. Land application is possible after all these treatment methods, but the heavy metal concentration of the remains has to be inside regulated limits. Other thermal processes include wet oxidation, pyrolysis, gasification, and utilization in a cement kiln. AD can be, wet or dry, mesophilic $\left(32-38^{\circ} \mathrm{C}\right)$ or thermophilic (minimum $55^{\circ} \mathrm{C}$ ) $[5,1]$, and a one-stage or two-stage process. The wet AD process is very suitable for the treatment of sewage sludge, which is usually really wet. The mesophilic process requires less energy in heating the process, but the digestate hygiene is worse. After the mesophilic process there is a need for composting, thermal drying or a hygienisation process $\left(70{ }^{\circ} \mathrm{C}\right.$ for at least $\left.30 \mathrm{~min}\right)$ before land application. [5]

The composting of sewage sludge requires mechanical drying, and after that a structural material is needed to get the moisture content into a proper lever for composting $(50-60 \%)$ and to allow better infiltration of air [6] Composting can be done outdoors in a static pile or in closed vessels. [5]

The conditioning of sludge before land application can be done by chemicals or thermally. Lime stabilization includes complete mixing of sludge and calcium oxide $(\mathrm{CaO})$. This can be done before or after sludge dewatering. The rise of $\mathrm{pH}(\mathrm{pH} \mathrm{12)}$ and the temperature rise (55 ${ }^{\circ} \mathrm{C}$ for two hours) reduce the risk of pathogen survival significantly, and thus make the sludge in most cases suitable for land application. Soil enrichment is partially caused by the possible lime application effect. Thermal drying can also be used in order to obtain suitable mass for land application. The temperature of $80{ }^{\circ} \mathrm{C}$ for at least 10 minutes and the final moisture content of less than $10 \%$ are required to obtain a product for land application. [5, 4]

Table 1. Typical characteristics of wastewater sludge. [1, 2]

\begin{tabular}{|l|l|l|l|l|l|l|}
\hline $\begin{array}{l}\text { TS } \\
\%\end{array}$ & $\begin{array}{l}\text { TVS } \\
\% \text { of TS }\end{array}$ & $\mathrm{pH}$ & $\begin{array}{l}\text { Alkalinity } \\
\mathrm{mg} / 1 \text { as } \mathrm{CaCO}_{3}\end{array}$ & $\begin{array}{l}\mathrm{N} \\
\%\end{array}$ & $\begin{array}{l}\mathrm{P}_{2} \mathrm{O}_{5} \\
\%\end{array}$ & $\begin{array}{l}\mathrm{K}_{2} \mathrm{O} \\
\%\end{array}$ \\
\hline $0.9-8$ & $59-88$ & $5.0-8.0$ & $500-1100$ & $1-8$ & $0.5-5$ & $<1$ \\
\hline
\end{tabular}

Table 2. Range of heavy metal contents in European Union countries [3]

\begin{tabular}{|l|l|l|l|l|l|l|l|}
\hline Metal & $\mathrm{Cd}$ & $\mathrm{Cr}$ & $\mathrm{Cu}$ & $\mathrm{Hg}$ & $\mathrm{Ni}$ & $\mathrm{Pb}$ & $\mathrm{Zn}$ \\
\hline $\mathrm{mg} / \mathrm{kg}_{\mathrm{DM}}$ & $04-3.8$ & $16-275$ & $39-641$ & $0.3-3$ & $9-90$ & $13-221$ & $142-2000$ \\
\hline
\end{tabular}

According to Crites et al. (2006), the combustion of sewage sludge requires a solid content of more than $26 \%$. [6] Combustion is considered an attractive method for treating sewage sludge, as it offers the following benefits: greater reduction of sludge volume, thermal destruction of toxic organic components, recovery of the energy content of the sludge, and minimization of odor generation. However, one of the major concerns is the pollutants created, and the heavy metal concentration of the remaining ash is too high for application to 
land and it is usually deposited into landfills [1]. Also the nutrient content of sewage sludge is mostly lost as the nitrogen ends up in flue gas.

\subsection{Wastewater sludge in the Leningrad Region}

In the Russian Federation the total production of wastewater is approximately 55 million $\mathrm{m}^{3} /$ day and $15 \%$ of all wastewater produced is untreated. More than 80 million $\mathrm{m}^{3}$ of wastewater sludge is produced every year in the Russian Federation. [2]

In the Leningrad Region, central wastewater treatment systems are in use in 30 cities, 33 towns and 222 urban communities. The total sludge production in the Leningrad Region is estimated to be over $54000 \mathrm{t}$ (dry matter, based on calculations according to Russian standards). [7]

So called aging is the most common method for wastewater sludge treatment in the Leningrad Region [8]. Aging means that the sludge is stored in piles, usually in sludge beds, from some months up to some years. After aging, the wastewater sludge is usually disposed to landfills or dumps. Aging is not an appropriate treatment method for wastewater sludge, because wastewater sludge treated by aging does not meet the sanitary and epidemiological requirements of the Russian Federation. Aging presents a sanitary hazard for the surrounding environment and the working personnel [8].

The situation with wastewater treatment has been improving during the last decade, but almost no attention has been paid to wastewater sludge treatment and disposal. According to estimates, nutrient loading from the municipalities is greater than from the agriculture [9]. Insufficient wastewater sludge treatment and disposal causes significant greenhouse gas emissions, pollution of local water basins and filling up of landfill sites.

\subsection{Objectives of the study}

The aim of this study was to define and discuss the properties of wastewater sludge from two different municipal wastewater treatment plants. The main properties defined in this study are total solids (TS) and total volatile solids (TVS), ash content, inorganic compounds, heavy metal contents, and the lower heating value of dry matter. The effect of the properties on energy and nutrient utilization are discussed.

\section{MATERIALS AND METHODS}

\subsection{Wastewater sludge}

The examined wastewater sludges come from two different municipal wastewater treatment plants in the Leningrad Region, Russia. The current method for wastewater sludge treatment in these wastewater plants is so called aging. Part of the wastewater sludge is used as a fertilizer, even though it is known that these sludges contain heavy metals.

\subsection{Sample collection}

The samples were collected in June 2010 from sludge beds; 2 mixed samples (one sample of fresh sludge and one sample of older sludge) in the towns of Tosno and Kommunar. For one mixed sample, 7 different samples were collected from different parts and depths of the sludge bed and mixed. 


\subsection{Analysis description}

The total solids (TS) of the samples were determined by drying the samples in $105^{\circ} \mathrm{C}$ for 2 hours. After this, the remaining sample was heated and volatilized in $550^{\circ} \mathrm{C}$ for 2 hours. The matter burned off in this process is the total volatile solids (TVS), and the remaining residue is ash.

The chemical elements were determined by Inductively Coupled Plasma-Atomic Emission Spectroscopy (ICP-AES), according to the standard EN ISO 11885. The amount of mercury was determined by Cold Vapor Atomic Absorption Spectroscopy, according to the standard SFS-EN 1483. Anions were determined with Ion Chromatography, according to the standard SFS-EN ISO 10304-1.

\section{RESULTS AND DISCUSSIONS}

\subsection{Characteristics of wastewater sludge}

The properties of examined wastewater sludge are presented in table 3. Tosno 1 and Tosno 2 are samples from Tosno, Kommunar 1 and 2 are samples from Kommunar. 1 is the fresh sludge sample and 2 is the older sludge sample.

When the results are compared to typical characteristics of sludge (table 1) it can be noticed that TS and ash are higher than typically. The reason for this can be that the wastewater sludge examined in this study was not collected directly from the wastewater treatment process. The samples were taken from sludge, that had been lying under open sky in the sludge bed. The wastewater sludge started to degrade biologically, and this had caused the higher TS and ash content.

Table 3. Properties of examined wastewater sludge.

\begin{tabular}{|l|r|r|r|r|}
\hline & Tosno 1 & Tosno 2 & Kommunar 1 & Kommunar 2 \\
\hline TS [\%] & 15.4 & 23.1 & 17.7 & 28.8 \\
\hline TVS [\% of TS] & 60.1 & 54.9 & 46.3 & 44.9 \\
\hline ash [\% of TS] & 39.9 & 45.1 & 53.7 & 55.1 \\
\hline
\end{tabular}

\subsection{Heavy metal contents}

The heavy metal contents (average results) of the wastewater sludge samples are shown in the table 4 .

When these results are compared to the limits of heavy metal contents for land application purposes in European Union countries, it can be noticed that only part of the cadmium and mercury content is too high. The limits for heavy metals in wastewater sludge for land application use are presented in table 5. In Russia, the limits are divided into two different groups. Group 1 limits are for all agricultural usage except for mushrooms, strawberries and green vegetables. Group 2 limits are for technical, forestry, flower and other cultures. 
Table 4. Heavy metal contents of the samples.

\begin{tabular}{|l|r|r|r|r|}
\hline Element & $\begin{array}{l}\text { Tosno 1 } \\
\mathrm{mg} / \mathrm{kg}_{\text {DM }}\end{array}$ & $\begin{array}{l}\text { Tosno 2 } \\
\mathrm{mg} / \mathrm{kg}_{\text {DM }}\end{array}$ & $\begin{array}{l}\text { Kommunar } 1 \\
\mathrm{mg} / \mathrm{kg}_{\text {DM }}\end{array}$ & $\begin{array}{l}\text { Kommunar 2 } \\
\mathrm{mg} / \mathrm{kg}_{\text {DM }}\end{array}$ \\
\hline $\mathrm{Pb}$ & 31 & 27 & 31 & 27 \\
\hline $\mathrm{Cd}$ & 37 & 28 & 31 & 35 \\
\hline $\mathrm{Ni}$ & 41 & 35 & 55 & 51 \\
\hline $\mathrm{Cr}$ & 19 & 14 & 37 & 24 \\
\hline $\mathrm{Zn}$ & 254 & 249 & 295 & 224 \\
\hline $\mathrm{Cu}$ & 80 & 67 & 207 & 165 \\
\hline $\mathrm{Hg}$ & 2 & 2.3 & 3.8 & 4.6 \\
\hline $\mathrm{As}$ & 0 & 0.7 & 0 & 0 \\
\hline
\end{tabular}

Table 5. Limits for pollutants in wastewater sludge for land application [10, 11, 12]

\begin{tabular}{|l|r|l|l|r|r|}
\hline Element & $\begin{array}{l}\text { Russia: } \\
\text { group 1 } \\
\mathrm{mg} / \mathrm{kg}_{\text {DM }}\end{array}$ & $\begin{array}{l}\text { Russia: } \\
\text { group 2 } \\
\mathrm{mg} / \mathrm{kg}_{\text {DM }}\end{array}$ & $\begin{array}{l}\text { Directive } \\
86 / 278 / \mathrm{EEC} \\
\mathrm{mg} / \mathrm{kg}_{\text {DM }}\end{array}$ & $\begin{array}{l}\text { Finland } \\
\mathrm{mg} / \mathrm{kg}_{\text {DM }}\end{array}$ & $\begin{array}{l}\text { USA } \\
\mathrm{mg} / \mathrm{kg}_{\text {DM }}\end{array}$ \\
\hline $\mathrm{Pb}$ & 250 & 500 & $750-1200$ & 100 & 840 \\
\hline $\mathrm{Cd}$ & 15 & 30 & $20-40$ & 1.5 & 85 \\
\hline $\mathrm{Ni}$ & 200 & 400 & $300-400$ & 100 & 420 \\
\hline $\mathrm{Cr}$ & 500 & 1000 & - & 300 & 3000 \\
\hline $\mathrm{Zn}$ & 1750 & 3500 & $2500-400$ & 1500 & 7500 \\
\hline $\mathrm{Cu}$ & 750 & 1500 & $1000-1750$ & 600 & 4300 \\
\hline $\mathrm{Hg}$ & 7.5 & 15 & $16-25$ & 1 & 57 \\
\hline
\end{tabular}

The examined samples do not contain too high heavy metal contents, except for cadmium. Compared to Finnish limits, also the mercury content is too high. In comparison to USA limits, the examined wastewater sludge could be utilized for land applications.

\subsection{Heating value}

Heating value is one of the most critical characteristics of wastewater sludge in the evaluation of the heat balances of wastewater sludge incineration. Usually, the lower heating value varies from 12 to $23 \mathrm{MJ} / \mathrm{kg}_{\mathrm{TS}}$. [13] In table 6, the lower heating values for the examined wastewater sludge samples are presented.

The heating values of the examined samples are lower what they are typically. The lower heating values in the arrival condition are negative or near to zero. The examined samples were collected from the sludge bed and their age was from some days to some months (samples Kommunar 1 and Tosno 1) and from some months to even over one year (samples Kommunar 2 and Tosno 2). During aging the wastewater sludge degrades, and this can cause relatively low heating values.

\subsection{Utilization possibilities}

There are several utilization possibilities for wastewater sludge. In this study, the following possibilities are examined:

- Agricultural use 
- Energy production

o combustion

0 biogas production and combustion of biogas

\subsubsection{Agricultural use}

Wastewater sludge can be utilized for agricultural purposes. It is a good source of nutrients, especially nitrogen and phosphorus, and it contains a lot of organic matter, which improves the physical properties of the soil. The samples studied in this research can not be utilized as a fertilizer in agriculture, because according to Russian legislation, their cadmium content is too high. One of the samples, Tosno 2, contains $28 \mathrm{mg} / \mathrm{kg}_{\mathrm{DM}}$ and it is below the 2 nd group limits. This means that according to GOST 17.4.3.07-2001, this sludge could be utilized for example in urban landscaping and forestry.

Table 6. The heating values for wastewater sludge samples.

\begin{tabular}{|l|r|r|}
\hline Samples & $\begin{array}{l}\mathrm{LHV}_{\text {DM }} \\
\mathrm{MJ} / \mathrm{kg}_{\text {DM }}\end{array}$ & $\begin{array}{l}\mathrm{LHV}_{\text {ar. }} \\
\mathrm{MJ} / \mathrm{kg}_{\text {w.m. }}\end{array}$ \\
\hline Kommunar 1 & 11.1 & -0.13 \\
\hline Kommunar 2 & 8.3 & -0.86 \\
\hline Tosno 1 & 12.3 & -0.16 \\
\hline Tosno 2 & 11.0 & 0.86 \\
\hline
\end{tabular}

\subsubsection{Energy production}

Wastewater sludge can also be utilized in energy production by incinerating the sludge or by collecting methane from sludge digestion. The calculations of energy production possibilities are based on the following assumptions and initial values:

- The estimated amount of wastewater sludge is based on the number of inhabitants connected to the wastewater network

o The number of inhabitants in Kommunar is 17300

o The number of inhabitants in Tosno is 36000

0 in both cities $75 \%$ of the population is estimated to be connected to the wastewater network

0 the annual yield of wastewater sludge is $34 \mathrm{~kg}_{\mathrm{DM}} /$ person, which is the average wastewater sludge production according to the statistics in Finland [2]

- Before combustion, the sludge is dewatered to $30 \% \mathrm{DM}$ content. The energy need for mechanical dewatering is $0.03 \mathrm{kWh} / \mathrm{kg}$ water [14]

- The methane yield in the wastewater is $445 \mathrm{~m}^{3} / \mathrm{t}_{\mathrm{TVS}}$ [15], [16]

- The methane content of biogas produced is $66 \%$ [15], [16]

- The lower heating value for methane is $35.6 \mathrm{MJ} / \mathrm{m}^{3}$

The average values were used for the properties of sludge in Kommunar and Tosno respectively. The results for energy production are presented in table 7 .

The calculations of heat release from biogas combustion and direct combustion show that the heat release from biogas combustion is greater than that from direct combustion. For a more accurate comparison of these methods, it is necessary to calculate the net energy from both of these methods. 
The calculations of the net energy by the two methods are based on the following assumptions and initial values:

- The internal energy consumption of the digestion plant is $25 \%$ of the energy content of the produced biogas

- The total efficiency for biogas energy production is $85 \%$

- The total efficiency for direct combustion is $85 \%$

The average values were used for the properties of sludge in Kommunar and Tosno respectively. The results for net energy production are presented in table 8 .

Table 7. The potential energy production.

\begin{tabular}{|l|r|r|r|l|l|l|}
\hline & $\begin{array}{l}\text { Amount } \\
\text { of sludge } \\
\text { t/a }\end{array}$ & $\begin{array}{l}\mathrm{LHV}_{\mathrm{DM}} \\
\mathrm{MJ} / \mathrm{kg}\end{array}$ & $\begin{array}{l}\mathrm{LVH}_{\mathrm{ar}} \\
\mathrm{MJ} / \mathrm{kg}\end{array}$ & $\begin{array}{l}\text { Direct } \\
\text { combustion } \\
\text { MWh }\end{array}$ & $\begin{array}{l}\text { Amount of } \\
\text { methane } \\
10^{3} \mathrm{~m}^{3} / \mathrm{a}\end{array}$ & $\begin{array}{l}\text { AD+ } \\
\text { combustion } \\
\mathrm{MWh}\end{array}$ \\
\hline Kommunar & 440 & 9.7 & 1.2 & 480 & 75 & 740 \\
\hline Tosno & 920 & 11.6 & 1.8 & 1470 & 120 & 1220 \\
\hline
\end{tabular}

Table 8. Net energy production.

\begin{tabular}{|c|c|c|}
\hline & $\begin{array}{l}\text { AD+ combustion } \\
\text { MWh/a }\end{array}$ & $\begin{array}{l}\text { Direct combustion } \\
\text { MWh/a }\end{array}$ \\
\hline Kommunar & 470 & 410 \\
\hline Tosno & 780 & 1250 \\
\hline
\end{tabular}

The calculations of net energy production from biogas combustion and direct combustion show that in the Kommunar using anaerobic digestion and biogas combustion is greater that from direct combustion. In Tosno net energy from direct combustion is greater than from biogas combustion.

In the anaerobic digestion process the amount of dry matter is changed only little. Part of the dry matter is converted to biogas. It can be estimated that amount of digestate in Kommunar is $1090 \mathrm{t} /$ year and Tosno $2440 \mathrm{t} /$ year (30\% dry matter content). Generally it is possible to utilize the end product of the digestion process, digestate, in agriculture. The direct combustion of wastewater sludge generates ash. The amount of ash is much less than the amount of feedstock. It can be estimated that the amount of ash in Kommunar is $240 \mathrm{t} /$ year and in Tosno $390 \mathrm{t} / \mathrm{year}$. It is possible to utilize the ash in agriculture. The content of heavy metals in both end products, digestate and ash, can be high due to the content of heavy metals in the wastewater sludge. It seems that in this case the utilization of the end products in agriculture is not possible.

\section{CONCLUSIONS}

In the studied wastewater sludge samples of Tosno and Kommunar town, the cadmium contents were higher than the Russian limits for land application use. One of the samples was valid for the Russian land application group 2 purposes. Therefore it seems that utilization of these sludges for agricultural usage is very limited. The cadmium values did not exceed the 
limits very much. So it could be possible in future to change the wastewater properties, with regulations on what may be put to the sewage, so that the cadmium concentrations would decrease enough. Energy recovery of wastewater sludge is possible. The yields of energy are rather low for both of the towns. So it seems that treatment of the sludge would be wise to integrate with treatment of other waste materials. The selection of technology for treatment is mostly dependent on waste treatment needs of other materials and on the possibilities to recover or dispose the end product of the treatment.

\section{ACKNOWLEDGEMENTS}

The research has been financed by the Ministry for Foreign Affairs, the city of Lappeenranta and the city of Kouvola.

\section{REFERENCES}

[1] Fytili, D. and Zabaniotou, D. 2008. Utilization of sewage sludge in Eu application of old and new methods- A review. Renewable and sustainable energy reviews, 12, 116-140.

[2] Ronald, J., L, Matthews, P., Roland, P., R., 2008. Global Atlas of Excreta, Wastewater Sludge, and Biosolids Management: Moving Forward the Sustainable and Welcome Uses of a Global Resource. United Nations Human Settlements Programme. ISBN: 978-92-1-132009-1. [3] European Commission, 2001. Disposal and recycling routes for sewage sludge. Part 3 Scientific and technical report. ISBN: 92-894-1800-1.

[4] Pöyry Environment. 2007. Lietteenkäsittelyn nykytila Suomessa ja käsitelymenetelmien kilpailukyky selvitys. (in Finnish)

http://www.mmm.fi/attachments/ymparisto/5AygHJ6y8/Lietteenkasittelyn_nykytila_Suomess a RAPORTTI_FINAL.pdf

[5] MMM. 2005. Maa- ja metsätalousministeriön ja Kasvintuotannon tarkastuskeskuksen ohje maataloudessa käytettävälle puhdistamolietteelle.

http://www.kunnat.net/attachment.asp?path=1;29;356;24897;51777;86783

[6] Crites, R. W., Middlebrooks, E.J., Reed, S. C. 2006. Natural Wastewater treatment systems. ISBN-10. 0-8493-3804-2. Publisher: CRC Press; 1 edition (August 24, 2005)

[7] Antishina, I., V., Delarov, D., A., Dievskiij, V., A., Zinoveva, E., I., Kurganov, N., N., Myrashko, I., I., Prohorov, B., V., Toropova, N., M., 2007. The environmental protection, environmental and radiation safety in the Leningrad Region in 2006. Information-analytical collection. St. Petersburg. 192p. (in Russian)

[8] Gaisina, Y., 2009. The current situation of sewage sludge and manure treatment in livestock enterprises in the Leningrad region. Master thesis.

[9] Finnish Environment Institute, 2009. Identification of Priority Measures to Reduce Eutrophication from North-West Russia into the Gulf of Finland. PRIMER. Baseline study.

[10] GOST 17.4.3.07-2001. State Standard "Nature Protection. Soils. Requirements for sewage sludge use for fertilization".

[11] Rantanen, P., Kangas, A., Valve, M., 2008. Lietteen loppusijoitus - esiselvitys (Disposal of sludge - preliminary survey). Reports of Finnish Environment Institute. ISBN: 978-95211-2969-8. (In Finnish)

[12] EPA, 1994. Land Application of Sewage Sludge. A Guide for Land Appliers on the Requirements of the Federal Standards for the Use or Disposal of Sewage Sludge, 40 CFR Part 503.

[13] Niessen W.R., 2002.Combustion and Incineration Processes. Marcel Dekker, New York, United

States of America. Third Edition. 696 pages. ISBN:978-0-8247-0629-6 
[14] Khalil, R., A., Jonassen, O., Bugge, M., Sørum, L., 2007. Options for the treatment of organic sludge - The move towards thermal processing. SINTEF Energy Research

[15] Luostarinen S., Luste S., Sillanpää M. 2009. Increased biogas production at wastewater treatment plants through co-digestion of sewage sludge with grease trap sludge from a meat processing plant. Bioresource Technology 100, p. 79-85

[16] Davidsson, Å., Lövstedt, C., la Cour Jansen J., Gruvberger C., Aspegren H. 2008 Codigestion of grease trap sludge and sewage sludge. Waste Management 28, 986-992. 